\title{
СИНТЕЗ ЛИПИДОВ ДЛЯ БОР-НЕЙТРОЗАХВАТНОЙ ТЕРАПИИ РАКА
}

\author{
О.Б. Жидкова, А.А. Друзина, В.И. Брегадзе \\ Лаборатория алюминий- и борорганических соединений, \\ Институт элементоорганических соединений им. А.Н. Несмеянова РАН, \\ 119991, Россия, Москва, ул. Вавилова, д. 28.
}

DOI: 10.19163/MedChemRussia2021-2021-237

E-mail:zolga57@mail.ru

В настоящее время наиболее перспективным методом борьбы с онкозаболеваниями представляется бор-нейтронозахватная терапия (БНЗТ) рака. Одним из технологичных способов направленной доставки лекарственных соединений в опухоль является использование их в виде липосом. Липосомальный транспорт может также активно применяться и для доставки в опухоль самых различных борных полиэдров, которые сами по себе не способным проникать через клеточные мембраны [1]. Поэтому создание борсодержащих липидов для дальнейшего образования липосомальных препаратов, имеющие в своем составе полиэдрические гидриды бора, является актуальной задачей. Так, по Cul-катализируемой реакции [3+2]-диполярного циклоприсоединения алкинов к азидам получены борсодержащие липиды [2]. Гидрофильная часть таких липидов содержит бис (1,2-дикарболлиды) кобальта и железа, а липофильная - холестерол. Полученные липиды могут быть использованы в качестве предшественников липосом, обеспечивающих избирательную доставку бора в опухолевые клетки для бор-нейтронозахватной терапии рака (БНЗТ).

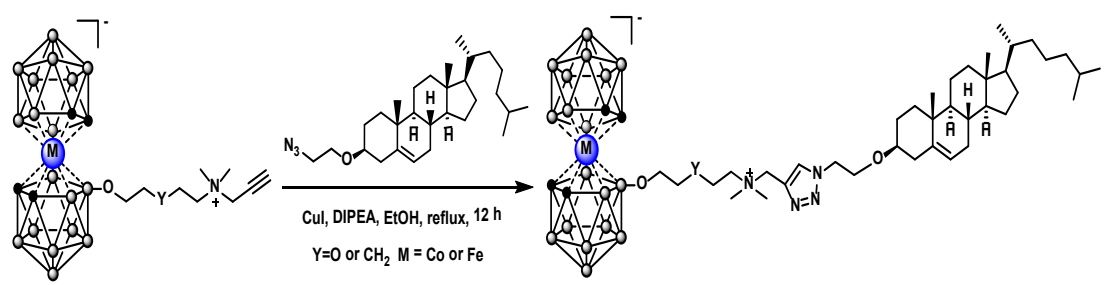

Работа выполнена при поддержке Российского фонда фундаментальных исследований (грант № 20-33-70011)

\section{Литература}

[1] D. Feakes, K. Shelly, C. Knobler and M. Hawthorne, Proc. Natl. Acad. Sci. USA. 1994, 91, 3029-3033.

[2] A. Druzina, I. Kosenko, O. Zhidkova, I. Ananyev, S. Timofeev and V. Bregadze, Eur. J. Inorg. Chem. 2020, 27, 2658-2668. 